\title{
Pricking Bubbles
}

\begin{abstract}
In the late 1980s and early 1990s, Japan mobilized monetary, prudential, tax, land, and fiscal policy tools, first to moderate the appreciation of the yen, then to contain the land price bubble, and finally to mitigate the shock of the bust. This chapter reviews the timeliness and the calibration of the policy measures taken and attempt a comparison with the monetary and prudential policy measures in the United States in the 2000s.
\end{abstract}

Keywords Bubble buster - Quantitative restriction - Clean/lean · Too-little-too-late

In the late 1980s and early 1990s, Japan's policy priorities shifted from moderating the appreciation of the yen to containing the land price hike and then to mitigating the deflationary effects of the collapse of the bubbles. Monetary, prudential, tax, land, and fiscal policy measures were mobilized; first eased to mitigate the appreciation of the yen, then tightened to stop the land price hike, and eased again to accommodate the shock from the collapse of the bubbles. 


\section{Monetary Policy}

For two years from February 1987 to May 1989, while the asset price bubbles continued to expand, the Bank of Japan kept its official discount rate at the post-war low of $2.5 \%$.

The fear of strong yen prevented the Bank from tightening earlier. Sumita Satoshi, the governor of the Bank of Japan from 1984 to 1989, later recounted, "If we had tightened, the yen would have appreciated. . .. The political sector, the industry, all were unanimous in demanding no stronger yen. Tightening was hard to do."l As soon as the yen plunged in May 1989, the Bank of Japan raised the rate.

The land price hike, which had been largely confined to Tokyo area, became a nationwide issue in 1989. The ratio of those who blame the government for its land and housing policy started to rise rapidly in late 1989. The public focus shifted from the yen to land. The "crazy land price" gave enormous windfall profits to landowners while depriving the dream to own a house from many, arousing a national anger.

Mieno Yasushi, who succeeded Sumita as the governor of the Bank of Japan in December 1989, stated at his inaugural press conference, "The nation is frustrated with the increasing wealth disparity among them resulting from the land and stock price boom." The finance minister demanded the governor to cancel the planned rate increase, but the governor did not take heed.

The Bank pursued tightening aggressively. It raised the rate three times in a half year, in May, October, and December 1989. Although the free fall in stock price commenced in January 1990, the Bank further raised the rate in March and August to 6\%. The rate was increased five times within a year and three months, amounting to 350 basis point increase. The stock market continued to tumble, but the Bank kept the rate at $6 \%$ for almost a year.

Mieno was considered as a defender of central bank independence and a brave bubble buster. The public applauded him comparing him to a champion-of-justice samurai-police commissioner in eighteenth century Japan, the protagonist of a popular novel series.

The easing started only in July 1991, well after the stock price peak (December 1989), the six large city land price peak (September 1990), the inflation rate peak (December 1990), and the business cycle peak (February 1991), and slightly before the nationwide land price peak (September 1991). The minister for economic planning criticized the 
Bank's tight monetary policy already in December 1990. Perhaps the minister knew better than the governor.

But at the time the Bank was largely surrounded by the hawkish public opinion. As late as in the autumn of 1991, major newspapers advocated, "Let's exterminate the land price bubble" (Asahi), "Bubble land prices shall not stay" (Mainichi), "Don't loosen land policy" (Yomiuri), "We cannot be relieved by moderated land prices" (Nikkei), and "Why rush to ease monetary policy?" (Tokyo). ${ }^{2}$

Ten years after, Ahearne et al. (2002), a team of economists at the US Federal Reserve Board, estimated that a further 200 basis point cut sometime between 1991 and early 1995 would have saved Japan from the chronic deflation, which haunted the country since the late 1990s. A Japanese politician gave an warning ten years earlier than them: Vice president Kanemaru of the ruling Liberal Democratic Party commented in February 1992 that, "even by chopping off the head of the Bank of Japan governor," a further 50 basis point cut had to be attained. One month later, the Bank reduced its policy rate by 75 basis points. It is said that the Bank had been in the process of a rate cut at the time of Kanemaru's remarks but that it chose to do so at a slightly different timing and size to protect the optics of central bank independence. ${ }^{3}$

The monetary policy moved largely in line with the shifts in public priorities from mitigating the strong yen, to containing the land price boom, and then to mitigating the effects of the bust. Governor Mieno, who took away the punch bowl while the party got going, was applauded as a champion of justice. When the effects of the land price bust manifested itself, however, the public changed their views and started to blame him for bringing in the crisis.

\section{Prudential Policy}

The Ministry of Finance, which then was the bank regulator, implemented from 1986 to 1989 a series of qualitative administrative guidance, gradually intensifying the measures (Table 3.1). In many other cases, guidance from regulators weaker than these had significant effects on the behavior of banks. ${ }^{4}$ But the series of actions taken during the frenzy in the latter half of 1980s, even though they went as far as reporting requirements, interviews with aggressive banks, and on-site inspections, could not curb the financing of real estate investments. 
Table 3.1 Guidance issued by the Ministry of Finance and the Bankers' Association

\begin{tabular}{|c|c|c|}
\hline April 1986 & $\begin{array}{l}\text { Circular issued by the Ministry } \\
\text { of Finance }\end{array}$ & $\begin{array}{l}\text { Request to behave so as not to } \\
\text { attract criticism that banks are } \\
\text { encouraging speculative land } \\
\text { deals } \\
\text { Reporting requirements on } \\
\text { land-related lending to real } \\
\text { estate and construction industries }\end{array}$ \\
\hline December & $\begin{array}{l}\text { Circular issued by the Ministry } \\
\text { of Finance }\end{array}$ & $\begin{array}{l}\text { Request to strictly refrain from } \\
\text { financing short-term resale of } \\
\text { lands }\end{array}$ \\
\hline \multirow[t]{2}{*}{ July 1987} & $\begin{array}{l}\text { Extraordinary interviews } \\
\text { conducted by the Ministry of } \\
\text { Finance }\end{array}$ & $\begin{array}{l}\text { Interviews on lending terms with } \\
\text { banks making large amount of } \\
\text { loans in regions showing } \\
\text { conspicuous rise in land prices }\end{array}$ \\
\hline & $\begin{array}{l}\text { "Common understanding" } \\
\text { published by the Bankers' } \\
\text { Association }\end{array}$ & $\begin{array}{l}\text { Confirmation that land-related } \\
\text { lending attitude shall be strictly } \\
\text { rectified }\end{array}$ \\
\hline \multirow[t]{2}{*}{ October } & $\begin{array}{l}\text { Circular issued by the Ministry } \\
\text { of Finance }\end{array}$ & $\begin{array}{l}\text { Request to be without flaws in } \\
\text { not making loans to finance } \\
\text { speculative land transactions } \\
\text { Request to make sure that } \\
\text { affiliated non-bank lenders shall } \\
\text { do the same }\end{array}$ \\
\hline & $\begin{array}{l}\text { Bankers' Association's } \\
\text { voluntary rules }\end{array}$ & $\begin{array}{l}\text { Elimination of lending to finance } \\
\text { speculative land transactions }\end{array}$ \\
\hline October 1989 & $\begin{array}{l}\text { Circular issued by the Ministry } \\
\text { of Finance }\end{array}$ & $\begin{array}{l}\text { Expansion of the scope of } \\
\text { extraordinary interviews } \\
\text { Reporting requirements on } \\
\text { lending to non-bank lenders } \\
\text { Mobilize on-site inspections to } \\
\text { contain lending to finance real } \\
\text { estate speculations }\end{array}$ \\
\hline March 1990 & $\begin{array}{l}\text { Circular issued by the Ministry } \\
\text { of Finance }\end{array}$ & Quantitative Restriction Circular \\
\hline
\end{tabular}

Note The underlined measure is quantitative, while others are qualitative Source Banking Bureau (1989, 1991)

However, the circular issued in March 1990 by the Ministry, or "the Quantitative Restriction Circular (QR)," made banks' real estate-related lending shut down abruptly.

The circular was a short, one-page document notifying the following two points: 
i. For the time being, each bank shall restrain the growth of loans to the real estate industry so that it would not surpass the rate of growth of all loans.

ii. For the time being, reports on lending to the real estate and construction sectors and non-bank lenders shall be submitted to the Ministry.

The Ministry initially hesitated to use quantitative measures, which it considered as retrogressing back to the command and control days and being inconsistent with the deregulation approach it had pursued. Though the prime minister and the minister of the National Land Agency both intensified requests for quantitative measures from mid-1989, the Ministry continued to resist. But, when the land price data released in March 1990 revealed that the frenzy had spilled from Tokyo over to Nagoya and Osaka, the prime minister was angered and instructed the minister of finance to consider further measures. The Ministry finally changed its mind and later in the month issued the QR circular. ${ }^{5}$

In September 1990, or six months after the issuance of the circular, the land price index for six large cities peaked out. In September 1991, the land price index for regions other than the six large cities also peaked out. The Ministry of Finance requested the National Land Agency to conduct an extraordinary land price survey, confirmed that the prices were not rising, and lifted the QR in December 1991. The lifting was five months after the first reduction in the official discount rate by the Bank of Japan.

The 1990 QR circular was followed by the collapse of the real estate bubbles, while the series of circulars in the late 1980s seem to have had no noteworthy impacts. One possible reason of this difference may have been that the former was comprehensive in coverage (it covered all land-related loans, whether related to speculative activities or not) and its implementation was monitored quantitatively, while the latter were not. A former high official of the Ministry provides another explanation: "After all it was a matter of timing. The circular was issued right at the time when bankers started to think that they went too far and had piled on too much exposure. They noticed that they were in danger and started to run away from real estate related lending."6 
Figure 3.1 shows survey responses of corporations in the real estate and manufacturing industries on banks' lending attitude to them. Tightening of banks' lending attitude to the real estate industry started a half year before the $\mathrm{QR}$ and at around the time of the first monetary policy tightening. The degree of the tightening, however, was far deeper for the real estate industry than for the manufacturing industry.

These may suggest that both the QR and the monetary policy affected the lending attitude. Perhaps the tightened monetary policy, bankers' growing awareness of their own excessive lending, and the QR reinforced each other and had unexpectedly strong aggregate effects.

Measures to contain bubbles tend to have bimodal effects: having no material impact or becoming a crashing blow. Multiple measures taken

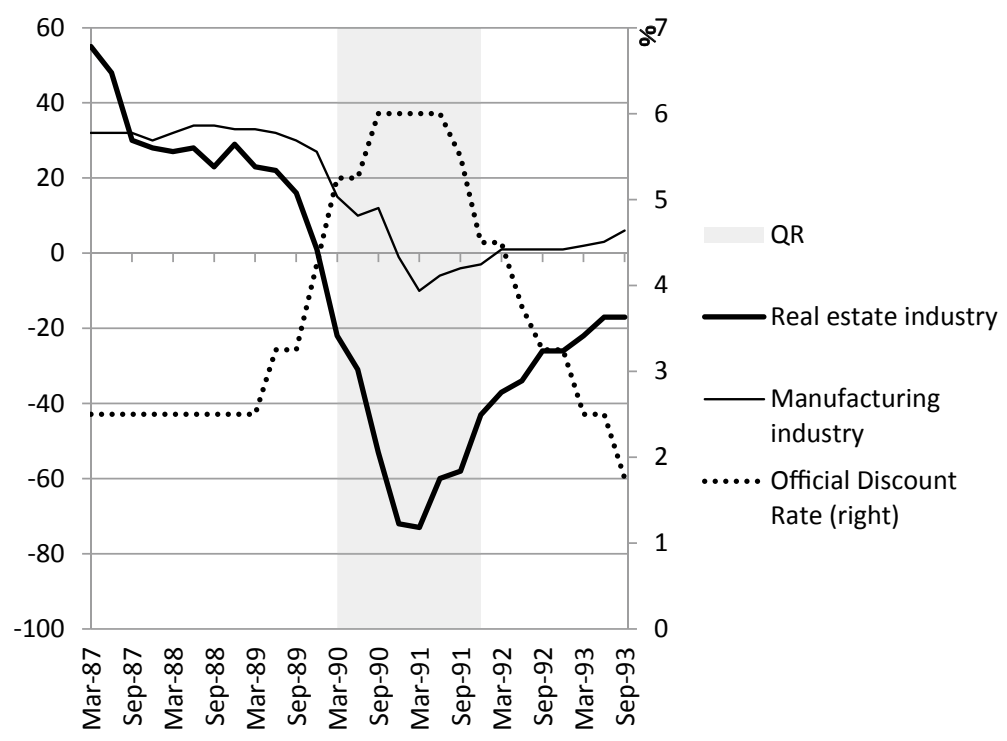

Fig. 3.1 Banks' lending attitude to the real estate and manufacturing industries (Note The level indicates the difference between the proportions of firms facing "easy" and "tight" bank lending attitude. Responses by companies of all sizes and on the current condition. Source The Bank of Japan, Short-term economic survey of enterprises [Tankan survey]) 
simultaneously may reinforce each other and have effects stronger than expected for each of the components.

The QR had stronger than anticipated effects, but it was hard to rescind it. As mentioned, even in autumn 1991, or right before the rescission, major newspapers were in unison in advocating extermination of the land price bubbles. According to another high official at the Ministry at the time, "My boss consulted me on lifting the QR. . . I dissuaded him from trying it, saying that public opinion would beat us up and the lifting would not go through the necessary political process. My boss could not give up his idea and wished he could have found some means to achieve it."7

The public supported the introduction of the QR and criticized its lifting but turned to accuse the $\mathrm{QR}$ when the land price bust resulted in a recession. Tanizawa (1995), a renowned literary critic, wrote about the director general who issued the circular, "Given the enormous loss he inflicted to the nation, sawing, spearing, tearing, crucifying, burning, and boiling that criminal would not be enough." Apparently, he was not aware that it was the director general who most strongly resisted the political pressures demanding the $\mathrm{QR}$ and tried hard to rescind it as quickly as possible. A popular science fiction comedy film Bubble Fiction: Boom or Bust released in 2007 depicted a heroine who used a time machine to go back to 1990, fought with the wicked director general, and successfully blocked the QR. The heroine then returned to 2007 Japan and found the country in glittering prosperity after two decades of continued boom.

\section{Tax, Land, ANd Fiscal Policies}

In addition to monetary and prudential policies, tax and land policies were mobilized to contain the real estate boom.

Starting with the tax law amendments in September 1987, a series of measures were taken to tighten taxation on land capital gains and on the holding of land. Some of the measures were implemented with significant delay and should have worked to accelerate the land price collapse. For example, the Land-Holding Tax was implemented with the rate of $0.2 \%$ from January 1992, when the land prices were declining nationwide, and the rate was raised to $0.3 \%$ in 1993 . It was maintained throughout the land price free fall until 1997, when the six-city area land price dropped to one quarter of the peak level. Another example was the appraised land 
prices for local tax on real estate holding: They long stayed far below the market prices but was raised dramatically in fiscal year 1993 .

The land policy moved from gesture to action only after the peak. The National Land Utilization Law was amended in June 1987 to introduce a system of land price monitoring zones. Local governments were given the power to designate monitoring zones, advise suspension or alteration of particularly inappropriate transactions, and publish the names of those who did not abide by the advice. The power, however, was rarely activated, as it was difficult to determine which transaction was speculative and inappropriate.

The land policy's new objective, namely, "crash the land myth" (which meant ending the widely held belief that land prices never fall), was announced as late as in January 1991, when land prices of the six large city areas had already peaked out, and was maintained all through the land price free-falls, with various new measures added to increase the supply of land. For example, in 1992, when land prices were falling across the country, it was made easier to transform land from agricultural use to residential use. In the same year, new forms of land lease contracts were introduced to provide more flexibility in the land-supply modality. The "crash the land myth" banner was replaced with "enhance liquidity in the real estate market" only in 1997.

Fiscal policy was mobilized to mitigate the recession in the wake of the collapse of the bubble. In March 1992, the government published a stimulus package and announced that the implementation of the public works budgeted for fiscal year 1992 would be front-loaded. In August 1992, an additional stimulation package with a total expenditure amounting to 10.7 trillion yen, equivalent to $2 \%$ of the GDP, was announced. Further stimulation packages ensued.

\section{Clean OR LEAN?}

Should we prick the bubble in advance or focus on mitigating the shock of busts? Should we rely on monetary policy or resort to prudential policy? There has been a century long debate on these issues, and diverse, sometimes opposite, lessons have been drawn from each of major crisis episodes, including the Great Depression, the Japanese banking crisis, and the Global Financial Crisis.

There was a debate between the Federal Reserve Board in Washington, DC and the Federal Reserve Bank of New York in the late 1920s on how 
speculations in the stock market should be contained. ${ }^{8}$ Washington was in charge of monetary policy, and did not want to use its own tool. It argued that, since the expected return on speculation was high, suppressing the speculations should require a massive policy rate increase, which would in turn halt sound productive activities. It wanted New York to do the job: Prudential policy tools (which then was called "direct pressure" on banks) could suppress speculations without damaging productive use of funds.

New York Fed, which was in charge of exerting direct pressure on banks, did not want to use its own tools either. It argued that, once member banks got the impression that they could not get money at any price, it might result in a critical situation. It wanted Washington to do the job: Speculative use of funds could not be distinguished from productive use, it was not possible to suppress only the former, and speculation could be contained only by monetary policy.

New York requested Washington to approve a discount rate increase for ten times, only to be rejected each time. The request was finally approved in August 1929, but the effect was mitigated by the reduction in bill rates, which was done to meet "productive fund demand."

The Black Monday and the Great Depression ensued. Two opposite lessons were drawn. Galbraith (1954) argued that the bubble should have been pricked decisively. According to him, Washington and New York avoided "an immediate and deliberately engineered collapse" and let a more serious disaster happen later on, because, (i) "a bubble can easily be punctuated" but "to incise it with a needle so that it subsides gradually is a task of no small delicacy," and (ii) someone would certainly be blamed for the ultimate collapse when it came anyway, but "there was no question whatever as to who would be blamed should the boom be deliberately deflated."

On the other hand, Bernanke (2002) considered that the Fed did too much to prick the bubble. Although "there was not the slightest hint of inflation," the Federal Reserve made "antispeculative" policy tightening and "the economy responded in the way that the monetary theory of the Great Depression would predict."

Similarly, Japan's bubbles and busts in the late twentieth century were interpreted in two opposite ways. At the Jackson Hall conference in 2003, Japan was named as a poster child of two opposing views. ${ }^{9}$

At the conference, Borio and White (2003), economists at the Bank for International Settlements, argued that monetary policy should be ready to 
lean against the build-up of financial imbalances even if near-term inflation pressures are not apparent. Responding to this, Michael Mussa, a former chief economist of the International Monetary Fund, commented, "It seems to me that the poster child for discussing why monetary policy should, in selected instances, pay serious attention to asset price distortions on the upside is not the United States in the late 1990s. It is Japan at the end of the 1980s. . . Looking at a CPI inflation rate that remained very low saw an enormous explosion of asset prices, real estate prices, and enormous growth of credit. If that price bubble collapsed, there was going to be serious macroeconomic problems."

Ben Bernanke did not agree: "I am astonished by Michael Mussa citing Japan as a poster child for this paper. It is just the opposite. . . The only place that monetary policy played a role was that in 1989 it intentionally tried to prick the bubble. It raised interest rates sharply in precisely the kind of program that is being suggested here. It did succeed in pricking the bubble. Asset prices collapsed and they had a 14-year depression."

After the Global Financial Crisis, the Cassandras who had warned against the build-up of financial imbalances strengthened their conviction. For example, White (2009) argue that the crisis demonstrated the need for monetary policy to focus more on "leaning" (i.e., preemptive tightening to moderate credit bubbles) than on "cleaning" (preemptive easing to deal with the after effects).

The main-stream view maintained its thrust after the crisis, but there have been some changes in nuances. The Federal Reserve acknowledged in its statement of longer-run goals and policy strategy in 2012 that the assessments of risks to the financial system was among the elements to be reflected in monetary policy decisions. The statement was amended in 2020 to place slightly more weights on a stable financial system, and an accompanying Q\&A on the amendment recognized that risks to the financial system are an important factor in the monetary policy decisions.

\section{Too Little, Too Late?}

Today many believe that Japan's responses to the boom and the bust in the late 1980s and early 1990s were too little, too late, while the US responses in the 2000s were decisive and timely. Bernanke and Gertler (1999) and Okina et al. (2001) argue that the tightening to contain the bubbles should have started earlier, while Hamada et al. (2011) claim that the easing to mitigate the shock of the bust started too late. As already mentioned, Ahearne et al. (2002) argue that more aggressive easing after the collapse would have saved Japan from deflation. 
Hamada et al. (2011) use the stock market price peak date as the benchmark in comparing the two episodes and argues, "In the US, the Federal Reserve Bank raised interest rates long before the stock market peaked, and cut rates very rapidly afterwards - indeed, had begun to cut before the peak. The Bank of Japan had been raising rates for some 18 months before the market peaked, and continued to raise them for over a year after the peak." The Federal Reserve appears to have behaved preemptively, while the Bank of Japan's behavior looks significantly belated.

But this comparison may entail two issues. First, the period between the start of the monetary policy tightening and the asset price peak may show how quickly the tightening (and other policy measures) worked, rather than how early the tightening started. We thus may want to look also at the period between the start of the bubbles and the start of the tightening. Second, the sequences of stock and real estate price peaks were reverse in the two episodes. In Japan, the stock price peaked nine months before the land price peak, while in the United States the real estate price peaked 18 months before the stock price peak. ${ }^{10}$ As Crowe et al. (2014) explains, what matters most for financial stability is the real estate bubbles, not the stock price ones.

Figure 3.2 uses the real estate price peak dates, rather than the stock price ones, as benchmarks. To review the timeliness of the start of the tightening, it looks at the early periods of bubbles as well as the peak periods.

The start of the real estate price bubbles is difficult to discern in both cases. Shiller (2005) considers that the "rocket taking off" in the home price market was in 1998, while the first tightening was in June 2004. The period between the start of the bubbles and the start of the tightening was about six years.

As to Japan, the start of the real estate price bubbles seems to be somewhere between 1985 and 1987. (Yoshikawa [2002] regards 1985 as the first year of the land price bubbles. Figure 3.2 shows a land price kink in the latter half of 1986. Okina et al. [2001] considers 1987 as the start of the bubble period.) The first tightening was in May 1989. The period between the start of the bubbles and the start of tightening would then be two to four years, shorter in any way than the six years in the United States. This comparison may imply that the tightening in Japan started in an earlier phase in the formation of the bubbles than in the United States.

But an opposite conclusion can also be drawn. The US residential real estate price had risen by $20 \%$ during the year preceding the start 


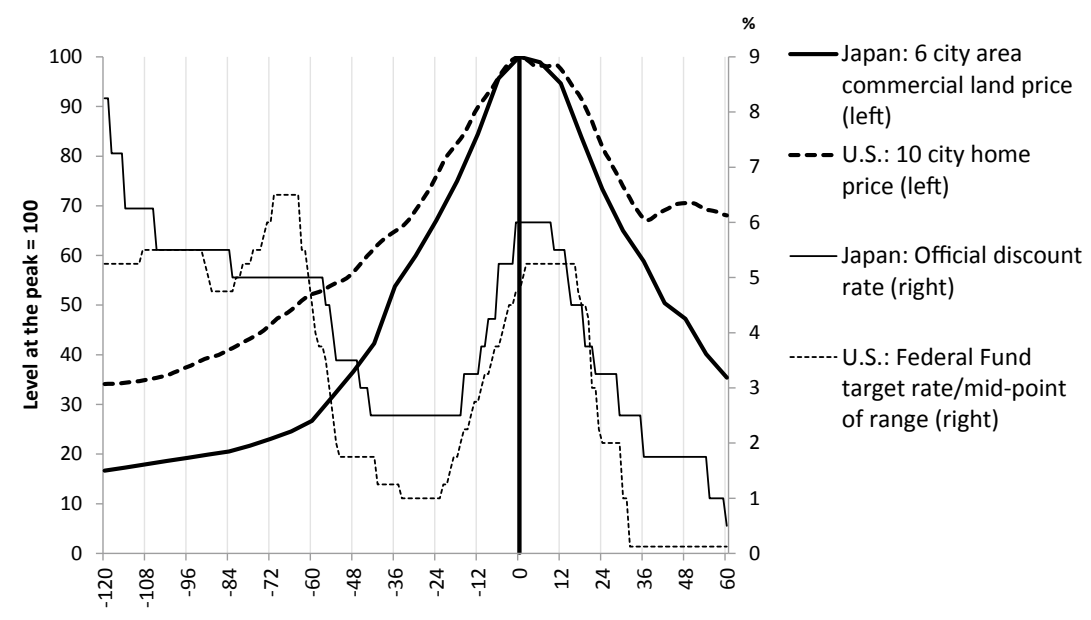

Months relative to peak (Japan: September 1990, U.S.: April 2006)

Fig. 3.2 Policy rates and real estate prices in Japan and the United States (Source Japan Real Estate Institute, Urban Land Price Index; S\&P Dow Jones Indices LLC, S\&P/Case-Shiller 10-City Composite Home Price Index; Bank of Japan, The Basic Discount Rate and Basic Loan Rate [Previously Indicated as "Official Discount Rates"]; and Board of Governors of the Federal Reserve System, Federal Funds Target Rate and Federal Funds Target Range)

of the tightening, up from the $13 \%$ rise during the year before that year. In Japan, the commercial land price had risen by $25 \%$ during the year preceding the start of the tightening, and the year before saw a $40 \%$ rise. This comparison would imply that Japan pushed down the brake pedal only after seeing an extreme exuberance, while the United States did so while the frenzy was still more moderate.

Was Japan later or earlier in starting the tightening? Figure 3.2 rather strikes us with similarity in the two episodes. In both episodes, the monetary policy was eased aggressively in the earlier phase of the real estate bubbles and was tightened pretty late in the cycle.

After the tightening, it took shorter period and smaller tightening to prick the bubbles in Japan than in the United States. The period between the start of the tightening and the real estate price peak was 16 months in Japan and 22 months in the United States. Japan tightened by 350 basis points and the United States by 425 basis points. Perhaps Japan saw the 
peak earlier with smaller tightening because (i) the frenzy was closer to the unsustainable level already at the time of the tightening and (ii) the QR brought forward the peak.

After the peak of the real estate prices, Japan started to ease a half year earlier but eased less aggressively than the United States. Japan started to ease 10 months after the real estate price peak, while the United States did so 17 months after. Japan eased by 225 basis points during the first year of easing, while the United States by 325 basis points; Japan by 350 basis points in the first two years, while the United States by 512.5 basis points.

In short, the trajectories of the monetary policies in the two episodes significantly resemble with each other throughout the cycle, with only minor differences in timing and calibrations.

One may say, however, that in measuring the degree of lean or clean, we should look at how much more the central banks did in addition to what was justified by the inflation and output condition at the time, rather than the absolute size of tightening and easing. Figure 3.3 compares the target rates suggested by the Taylor rule as proposed by Taylor (1993) (thin lines) and the actual policy rates (thick lines). Multiple target rates are shown using different estimates of the GDP gap.

Many believe that the Bank of Japan leaned to prick the bubble. But Japan did not lean more than the Taylor target. The Federal Reserve advocated that leaning was harmful and that cleaning after the bust was enough. The United States, however, did not clean more than the Taylor target. The major deviations in Japan from the Taylor target happened in 1986, when the easing was less aggressive than suggested by the rule. Perhaps if more had been done to mitigate the recession triggered by the rapid appreciation of the yen, the trough could have been shallower, and the ensuing frenzy to stimulate the domestic demand and the resultant boom could have been moderated. The major deviation in the United States was at an early phase of the bubble in 2004, when tightening was less aggressive than the rule.

There was a difference in rhetoric: The Bank of Japan used leanstyle languages and the Federal Reserve advocated a clean doctrine. It seems that, however, their behavior did not differ as much as the rhetoric suggests.

Also, the prudential policies in the two countries shared many common features. 

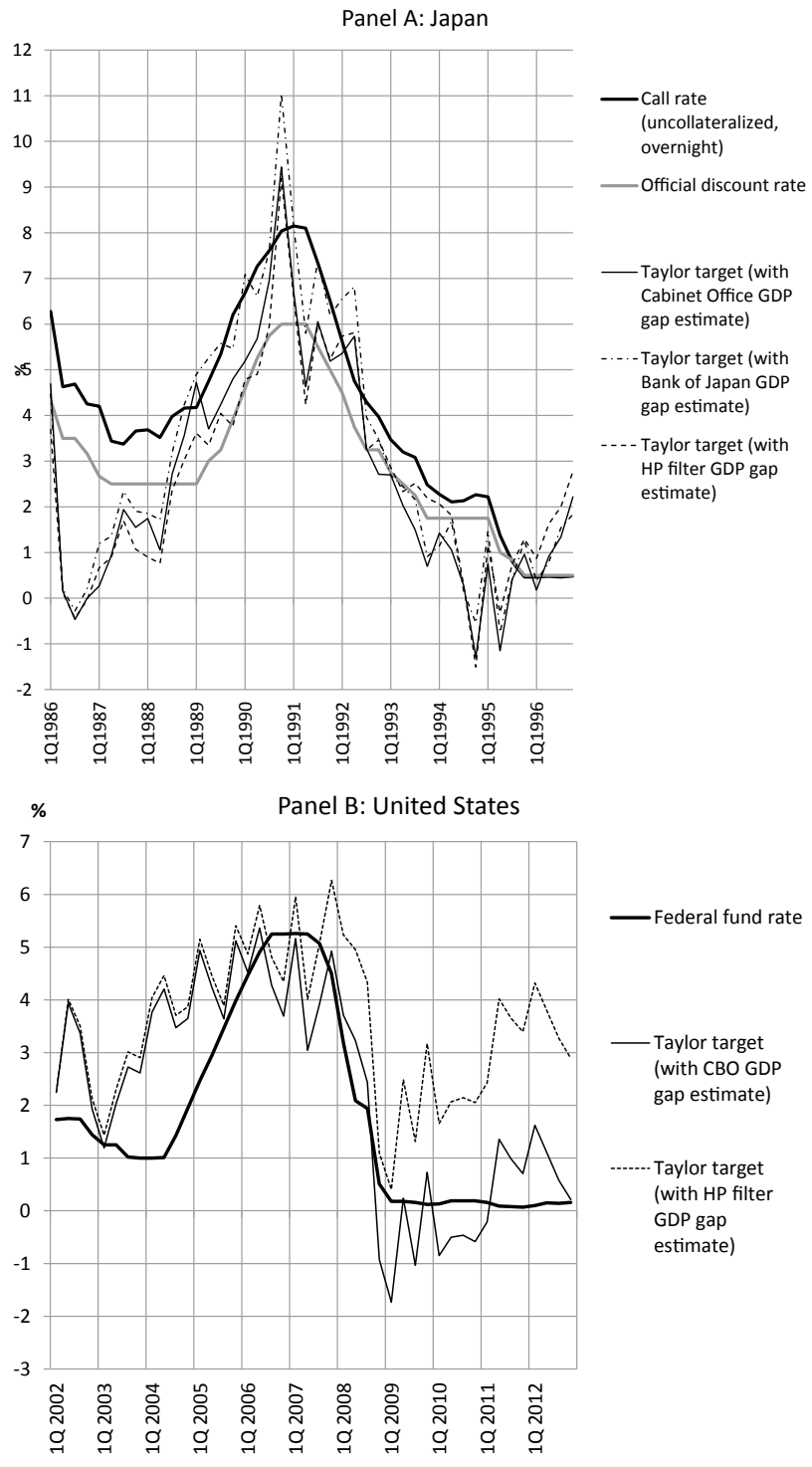

Fig. 3.3 Actual policy rates compared with Taylor targets (Source Himino 2016) 
In the United States, as Table 3.2 shows, the federal regulators started to issue interagency guidelines in 1999 , seven years before the residential real estate price peak and eight years before the commercial real estate price peak. They continued to add guidelines as the bubble grew, and after the residential real estate price peak in April 2006, implemented quantitative restrictions on commercial real estate-related lending (October 2006). A half year after the start of the restriction, the commercial real estate price peaked.

Regulators in Japan and the United States both started to introduce qualitative guidance very early in the boom, added layers of guidance as the bubble grew, and only after the initial signs of a bust, introduced quantitative limits, finishing off the boom and deepening the bust.

Table 3.2 Supervisory guidance issued by US authorities

March 1999

October

December

January 2001

February 2003

October

April 2004

February 2005

March

May

May

September

October 2006

October

December

June 2007
Interagency Guidance for Subprime Lending Interagency Guidance on High Loan-to-Value (LTV) Residential Real Estate Lending Interagency Guidance on Asset Securitization Activities Expanded Guidance for Subprime Lending Programs Interagency Advisory on Mortgage Banking Interagency Guidance on Independent Appraisal and Evaluation Functions Interagency Guidance on Unfair or Deceptive Acts or Practices by State-Chartered Banks

Interagency Guidance on the Detection, Investigation, and Deterrence of Mortgage Loan Fraud Involving Third Parties Interagency FAQs on the Agencies' Appraisal Regulations and Interagency Statement on Independence of Appraisal and Evaluation Functions

Interagency Credit Risk Management Guidance for Home Equity Lending

Accounting and Reporting for Commitments to Originate and Sell Mortgage Loans

Interagency FAQs on Residential Tract Development Lending Interagency Guidance on Nontraditional Mortgage Product Risks Addendum to the May 2005 Interagency Credit Risk Management Guidance for Home Equity Lending Interagency Guidance on Concentration in Commercial Real Estate Lending, Sound Risk Management Practices Statement on Subprime Mortgage Lending

Note The underlined measure is quantitative, while others are qualitative

Source Cole (2007); Federal Reserve Board, Supervisory Policy and Guidance Topics: Real Estate (https://www.federalreserve.gov/supervisionreg/topics/real_estate.htm, accessed in November 2020) 


\section{In Hindsight}

In hindsight, it seems that the monetary easing and major fiscal stimulus added in 1987, when the economy was recovering and the rapid land price hike started, may have been excessive. It may have been too late that monetary tightening started only in 1989. The QR should have been introduced earlier if it should have been introduced at all. The official discount rate was raised to $6 \%$ in 1990 , when the stock price was plummeting and the six large city area land price peaked out. The QR was rescinded and the official discount rate was reduced only in the latter half of 1991. The combined effects of the monetary policy tightening and the QR may have been excessive in aggregate. In addition, perhaps the QR lasted too long.

The following four reasons may explain the delay in policy changes.

First, policy priorities other than moderating the boom and the bust prevented timely responses. The measures to contain bubbles were delayed as they were thought to conflict with the need to suppress the yen appreciation. The change in policy direction from containment of bubbles to the mitigation of their collapse was delayed as it was thought to go against the "crash the land myth" banner.

Policy choices have to be made under pressure from the public opinion and the political sector. Japan's experience shows that pressure can work in both directions, tightening and easing. Experts made better judgments in some cases, but in other, those who exerted pressure on experts seem to have had better insights. Policy authorities should try to engage constructively with the political sector and the public opinion, not taking the matter as a game of giving-in or not. If insights on the dynamics of bubbles and on the effects of policy measures could be shared widely in the society, constructive engagements would become easier.

Second, recognition lag may explain part of the delay. The land price indices during the period under study were published infrequently and with significant delays. Almost one year was needed to confirm the peak out of the land prices. ${ }^{11}$ When it comes to making timely policy decisions, the Japanese authorities in the 1990s were far more disadvantaged than their US counterparts in the 2000s. ${ }^{12}$ Today, more timely information is available in Japan than in the 1990s. ${ }^{13}$

The recognition lag is also significant regarding the peaks and troughs in business cycles. Seven months after the February 1991 peak, the government's monthly economic report modified its view from "in an 
expansion trend" to "still expanding with gradual deceleration" and after 11 months to "in an adjustment process." There are often several percentage points of difference between the first, second, and final estimates of the GDP growth rate. The final estimate is published nine to 18 months after the end of the estimated quarter. More frequent publication of more accurate economic statistics with smaller delay would help enable timely policy actions.

Prices of different asset classes peak out not simultaneously. The sequencing of the stock price peak and the real estate price peak was in reverse between Japan in the late 1980s and early 1990s and the United States in the 2000s. We cannot predetermine which index is a leading indicator. This makes the task of ascertaining a turning point even more difficult.

Third, the tax and land policy measures to reduce land prices were kept long after the collapse of the bubbles, perhaps because they had different objectives from those of macroeconomic or prudential policies.

For financial stability, the changes in land prices matter more than the level, but the levels matter more for taxation and redistribution purposes, since declining but high land prices still indicate land holders' capability to bear the tax burden. The levels matter more also for land policy, which aims to enable people to use land at reasonable prices.

Fourth, the Japanese authorities acted without the knowledge of what the bubbles and the crushes would cause later. This could have disadvantaged them.

But, even though the US authorities were well aware of what happened in Japan and were determined not to repeat its mistakes, the US monetary and prudential policies in the 2000s did not differ much from Japanese ones in the late 1980s and early 1990s. Knowing about others' mistake alone may not be enough to avoid repeating it ourselves.

\section{Notes}

1. Nihon Keizai Shinbunsha (2000).

2. Nishimura (1999).

3. Kamikawa (2002).

4. For example, the Financial Services Agency in December 2006 added a footnote on the current conditions of the real estate market in its annual supervisory policy statement. The director general in charge published a related article in a business magazine. These gestures worked to contain the emerging real estate froth. 
5. Karube (2015).

6. Nakai (2011).

7. Nishimura (1999).

8. For a lively and highly interesting description of the debate, see Chapter 6 of Friedman and Schwartz (1963).

9. Federal Reserve Bank of Kansas City (2003).

10. In Japan, the Nikkei 225 stock price index peaked in December 1989 and then six city area commercial land price index peaked in September 1990. In the United States, S\&P Case-Shiller 10-City Home Price Index (Seasonally Adjusted) peaked in April 2006 and then the S\&P 500 Stock Price Index peaked in October 2007.

11. The Urban Land Price Index by the Japan Real Estate Institute has been published semiannually and with a two-month lag. One could have noticed the start of a slight decline in six city area land price only eight months after the peak and could have confirmed a clear sign of decline only one year and two months after. If one used the Land Price Public Notice (January price with two month delay) and the Market Values of Standard Sites (July price with two month delay) both published by the National Land Agency, a similar recognition should have required four to six more months.

12. The Case-Shiller home price index and the Office of Federal Housing Enterprise Oversight home price index were published monthly with a two-month delay, and the First American Core Logic house price index monthly with a five week delay.

13. Available indices include: the Recruit Residential Price Index (monthly with one month delay), the Tokyo Stock Exchange Home Price Index (monthly with two month delay), the Japan Residential Property Price Index (monthly with four month delay) and the Trend Report of the Values of Intensively Used Land in Major Cities (quarterly).

\section{REFERENCES}

Ahearne, A. G., Gagnon, J., Haltmaier, J., Kamin, S. B., Erceg, C. J., Faust, J., \& Wright, J. H. (2002). Preventing deflation: Lessons from Japan's experience in the 1990s (FRB International Finance Discussion Paper, No. 729).

Banking Bureau of the Ministry of Finance (Okurasho Ginko-kyoku). (1989). The 38th annual report of the Banking Bureau (Dai 38 kai Ginkoukyoku Kin'yuu Nenpou). Kin'yuu Zaisei Jijou Kenkyuukai.

Banking Bureau of the Ministry of Finance (Okurasho Ginko-kyoku). (1991). The 40th annual report of the Banking Bureau (Dai 40 kai Ginkoukyoku Kin'yuu Nenpou). Kin'yuu Zaisei Jijou Kenkyuukai. 
Bernanke, B. S. (2002). On Milton Friedman's ninetieth birthday. In B. S. Bernanke (Ed.), Remarks at the conference to honor Milton Friedman. Chicago: University of Chicago.

Bernanke, B. S., \& Gertler, M. (1999). Monetary policy and asset volatility. Federal Reserve Bank of Kansas City Economic Review. Fourth Quarter 1999, 84(4), 17-52.

Borio, C., \& White, W. R. (2003). Whither monetary and financial stability: the implications of evolving policy regimes. In Proceedings-Economic Policy Symposium-Jackson Hole. Federal Reserve Bank of Kansas City.

Cole, R. (2007, March 22). Subprime mortgage market. Testimony before the U.S. Senate Committee on Banking, Housing, and Urban Affairs.

Crowe, C., Dell'Ariccia, G., Igan, D., \& Rabanal, P. (2014). Policies for macrofinancial stability: Managing real estate booms and busts. In S. Claessens, A. Kose, L. Laeven, \& F. Valencia (Eds.), Financial crises: Causes, consequences, and policy responses (pp. 365-396). International Monetary Fund.

Federal Reserve Bank of Kansas City. (2003). Monetary Policy and Uncertainty: Adapting to a Changing Economy. Kansas City.

Friedman, M., \& Schwartz, A. J. (1963). A monetary history of the United States, 1867-1960. Princeton: Princeton University Press.

Galbraith, J. K. (1954). The great crash 1929. Boston: Houghton Mifflin.

Hamada, K., Kashyap, A., \& Weinstein, D. (2011). Introduction. In K. Hamada, A. Kashyap, \& D. Weinstein (Eds.), Japan's bubble, deflation, and long-term stagnation. Cambridge: The MIT Press.

Himino, R. (2016). Japanese responses to asset price bubbles: Comparison with the US. Public Policy Review, 12(2), 253-290.

Kamikawa, R. (2002). The bubble economy and the Bank of Japan independence (Baburu keizai to nihon ginkou no dokuritsusei). In M. Muramatsu \& M. Okuno (Eds.), Studies on Heisei bubbles, book 1, formation (Heisei baburu no kenkyu, Jou, Keisei hen). Toyo-keizai.

Karube, K. (2015). Examination of the policy failures in dealing with the bubbles (Kenshou baburu shissei). Iwanami.

Nihon Keizai Shinbunsha. (2000). Reviewing the bubbles: Mistakes made without intent (Kensho baburu han'i naki ayamachi). Nikkei Bijinesujin Bunko.

Nishimura, Y. (1999). Why did the financial regulators fail? (Kinyu gyosei no haiin). Bunshun Bunko.

Okina, K., Shirakawa, M., \& Shiratsuka, S. (2001). The asset price bubble and monetary policy: Japan's experience in the late 1980s and the lessons. Monetary and Economic Studies, 19(2), 395-450.

Sei Nakai, S. (2011). Mr. Sei Nakai, 2nd interview, part 2, oral history (Dai 2 bu ooraru hisutori 2 nakai sei shi). In S. Matsushima \& H. Takenaka (Eds.), Oral history, Book 3, records on the Japanese economy (Nihon keizai no kiroku, 
3, Jidai shougen shu, Oraru hisutori). Economic and Social Research Institute, Cabinet Office.

Shiller, R. J. (2005). Irrational exuberance. New York: Broadway Books. Taylor, J. B. (1993). Discretion versus policy rules in practice. Carnegie-Rochester Conference Series on Public Policy, 39, 195-214.

Tanizawa, E. (1995). Wisdom on Human Being (Ningen tsuu). Shincho-sha. White, W. R. (2009). Should monetary policy lean or clean'? (Federal Reserve Bank of Dallas, Globalization and Monetary Policy Institute Working Paper No. 34).

Yoshikawa, H. (2002). Land bubbles-Causes and backgrounds (Tochi baburugen'in to jidai haikei), Chapter 9. In T. Muramatsu \& M. Okuno (Eds.), Studies on bubbles in Heisei-era, Book 1 (Heisei Baburu no Kenkyu Jou). Toyokeizai.

Open Access This chapter is licensed under the terms of the Creative Commons Attribution-NonCommercial-NoDerivatives 4.0 International License (http:// creativecommons.org/licenses/by-nc-nd/4.0/), which permits any noncommercial use, sharing, distribution and reproduction in any medium or format, as long as you give appropriate credit to the original author(s) and the source, provide a link to the Creative Commons license and indicate if you modified the licensed material. You do not have permission under this license to share adapted material derived from this chapter or parts of it.

The images or other third party material in this chapter are included in the chapter's Creative Commons license, unless indicated otherwise in a credit line to the material. If material is not included in the chapter's Creative Commons license and your intended use is not permitted by statutory regulation or exceeds the permitted use, you will need to obtain permission directly from the copyright holder.

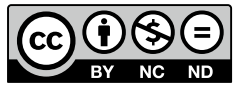

